\title{
Assessment of exotic fish disease introduction and establishment in the United Kingdom via live fish transporters
}

\author{
E. J. Peeler* , M. A. Thrush \\ Centre for the Environment, Fisheries and Aquaculture Science, Barrack Road, The Nothe, Weymouth DT4 8UB, UK
}

\begin{abstract}
Live fish transporters returning empty from mainland Europe may mechanically introduce exotic pathogens and parasites to the UK. A qualitative risk assessment approach was adopted to investigate the likelihood of introduction and establishment in rainbow trout farms of viral haemorrhagic septicaemia (VHS), infectious haematopoietic necrosis (IHN) and Gyrodactylus salaris via this route. A scenario tree was developed and estimates made for the likelihood of each step based on a review of the available information. The level of uncertainty associated with each step was qualitatively assessed. The likelihood of a lorry becoming contaminated with any of the 3 hazards was only greater than negligible if the lorry made movements between farms in mainland Europe. In these circumstances, the overall likelihood of introduction and establishment was extremely low (would occur very rarely), extremely low to negligible and very low (would occur rarely) for VHS, IHN and G. salaris, respectively. A high level of uncertainty existed due to the lack of data on farm-level prevalence, minimum infectious dose (of the viral hazards) and the large variability in duration and conditions of transport. A telephone survey of live fish transporters found that cleaning and disinfection practices after return to the UK were implemented. Currently, no UKbased transporters make movements between farms in mainland Europe. Thus, the likelihood that UK-owned transporters may become infected is negligible. Changes in the way in which UK-based live fish transporters operate in mainland Europe need to be monitored and development of a code of practice to minimise the risk of disease introduction considered.
\end{abstract}

KEY WORDS: Risk analysis $\cdot$ Fish pathogens $\cdot$ Mechanical transmission $\cdot$ Transporters

\section{INTRODUCTION}

The UK is free of a number of serious notifiable diseases of fish that are found in mainland Europe. The main route for the spread of infectious disease agents both within and between countries is the movement of live fish. Current EU legislation (EC Directive 2006/88) minimises the risk of notifiable disease transmission by only allowing live fish to be moved between zones or countries of the same disease status (or from higher to lower disease status). The UK, therefore, is protected against the introduction of exotic notifiable pathogens via the movement of live fish. However, free-living parasites and pathogens can be mechanically trans- ported by the movement of vehicles, people and equipment (i.e. by fomites). The importance of mechanical transmission depends on the survival of the pathogen outside the host and also on environmental conditions. In the 2001 foot and mouth epidemic in the UK, mechanical transmission was an important route of short and long distance spread (Anderson 2002). There is evidence that aquatic animal diseases have also been spread mechanically. Anguillicola crassus, a nematode infection of eels Anguilla anguilla, is thought to have been introduced to the UK by transporters sent empty to the UK to collect eels for farming and consumption in Europe (Kennedy \& Fitch 1990). Sharing equipment between sites probably resulted in 
the spread of infectious haematopoietic necrosis virus (IHNV) in France (Hattenberger-Baudouy et al. 1988) and in British Columbia (Hattenberger-Baudouy et al. 1988, St-Hilaire et al. 2002). Epidemiological studies of infectious salmon anaemia (ISA) have identified potential routes of mechanical transmission, including divers (Hammell \& Dohoo 1999) or other members of the workforce moving between sites (Vagsholm et al. 1994), boats delivering feed (Hammell \& Dohoo 1999) and well-boats transporting harvested Atlantic salmon Salmo salar between farm sites (Murray et al. 2002). The movement of live fish transporters, returning empty to the UK from mainland Europe was identified by Peeler \& Thrush (2004) as a potential route of entry for the exotic salmonid parasite Gryodactylus salaris.

In the present paper we describe a risk assessment to investigate the potential for live fish transporters, moving from mainland Europe to the UK, to mechanically introduce Gryodactylus salaris and the exotic viral pathogens of salmonids, viral haemorrhagic septicaemia virus (VHSV) and IHNV, all of which are present in farmed rainbow trout Oncorhynchus mykiss in mainland Europe. Risk analysis methods were originally developed by the mining and petrochemical industries to assess the likelihood and consequences of adverse events. They have more recently been applied to biological systems. Their use in animal health has largely focused on the introduction of exotic pathogens via the international trade in animal and animal products: import risk analysis (IRA). Most recently, the risk of introducing viral haemorrhagic septicaemia virus to Chile via sardine Sardina pilchardus exports from Europe has been investigated (Hervé-Claude et al. 2008). IRA has been largely driven by the Agreement on the Application of Sanitary and Phytosanitary Measures of the World Trade Organisation (WTO 1995) (known as the SPS agreement), which requires an IRA to justify sanitary measures over and above those sanctioned by international agreement. IRAs are, therefore, often initiated in response to proposed importations of animals or animal products and thus are conducted to determine whether trade should take place and, if so, under what conditions. However, an IRA may be used more broadly to help determine appropriate biosecurity measures to minimise the likelihood of exotic disease introductions (Peeler et al. 2007). The present paper assesses the likelihood of pathogen introduction given current practices, to support the development of biosecurity strategies and to identify priorities for future research.

\section{MATERIALS AND METHODS}

The likelihood of the introduction and establishment of VHSV, IHNV and Gryodactylus salaris through the movement of an empty live fish transporter from a rainbow trout farm in mainland Europe to England and Wales is qualitatively assessed. The assessment considers the likelihood that the pathogens are present on the vehicle in residual pools of water, sediment, in empty tanks or on equipment (nets, discharge pipes etc.), or in dead or dying fish accidentally left on the vehicle. The likelihood of the introduction and establishment of these pathogens is assessed for a single lorry. The data required for a quantitative analysis are identified. An unrestricted (i.e. without risk mitigation) and restricted risk assessment were undertaken. The consequences of the establishment of the disease agents are not considered. The results of this analysis are used to determine whether a full quantitative analysis is required.

The import risk analysis method recommended by the World Organisation for Animal Health (OIE 2001, 2006) has been adopted for our analysis. Hazard identification precedes the risk assessment, which has 4 components: (1) release assessment (description of pathways necessary for introduction), (2) exposure assessment (description of pathways necessary for the exposure of aquatic species in the importing country to the introduced exotic pathogen), (3) consequence assessment (likelihood of establishment and identification of the consequences of disease), and (4) risk estimation (results of the previous 3 stages are integrated). Risk management and risk communication are considered within the risk analysis umbrella but are undertaken separately from the risk assessment process. Here, we consider the release assessment, exposure assessment and the likelihood of establishment (an element of consequence assessment).

The scenario tree (see Fig. 1) represents the sequence of events necessary for the release, exposure and establishment of these exotic pathogens via the movement of live fish transporters. Information on the geographic distribution of the pathogens in Europe, their epidemiology and biophysical characteristics were reviewed and used in estimating the likelihood for each step in the pathway.

Descriptive terms are used to assess the likelihood associated with the introduction of pathogens with live fish transporters at each step in the scenario tree (given that the previous steps have taken place). The qualitative terms used are described in Table 1. An estimate of the combined uncertainty (due to incomplete data) and variability (due to observed biological variation) associated with the estimate was also made (high, medium and low). The method used in a recent European Food Safety Authority (EFSA) report (EFSA 2007) was employed to combine qualitative estimates. Using the matrix given in Table 2 the likelihoods of Step 1 and Step 2 were combined to give a conditional likeli- 
Table 1. Description of terms used to describe the risk of fish pathogens or parasites being introduced to the UK (after Kahn et al. 1999)

\begin{tabular}{|ll|}
\hline Likelihood & Description \\
\hline High (H) & Expected to occur \\
Moderate (M) & Occurrence less than $50 \%$ \\
& probability \\
Low (L) & Unlikely to occur \\
Very low (VL) & Rarely occur \\
Extremely low (EL) & Very rarely occur \\
Negligible (N) & Chance of occurrence so \\
& small it can be ignored \\
\hline
\end{tabular}

Table 2. Matrix used to produce the pathway conditional likelihood for routes of disease introduction and establishment. H: high, M: moderate, L: low, VL: very low, EL: extremely low, $\mathrm{N}$ : negligible (lowest possible likelihood). N-EL combined with a likelihood $\mathrm{L}$ reduces to negligible

\begin{tabular}{|ccccccc|}
\hline \multirow{2}{*}{$\begin{array}{c}\text { Likelihood at } \\
\text { Step ' } n+1 \text { ' }\end{array}$} & N & EL & VL & L & M & H \\
\hline H & N & EL & VL & L & M & M \\
M & N & EL & VL & VL & L & M \\
L & N & EL & EL & VL & VL & L \\
VL & N & N-EL & EL & EL & VL & VL \\
EL & N & N & N-EL & EL & EL & EL \\
N & N & N & N & N & N & N \\
\hline
\end{tabular}

hood, which was then combined with the likelihood of Step 3, and so on.

A telephone survey was conducted to establish current risk management practice. British fish farms rearing trout or salmon and owning fish transporting vehicles, and haulage contractors specialising in live fish transport (five of which routinely operate overseas), participated in the telephone survey which was designed to assess lorry disinfection and other risk reduction practices. Live fish transporters were identified through advertisements in the trade press and through informal interviews with individuals involved in the trade. In total, 16 operators were contacted. Only 5 of the large operators were found to operate in mainland Europe.

\section{RESULTS}

\section{Current situation}

Hazard identification. The UK has been approved as having pathogen-free status for VHSV and IHNV, the 2 viral diseases listed under European legislation as notifiable (List II) diseases (EC Directive 91/67) and Gyrodactylus salaris (European Commission Decision
453/2004). These pathogens are found in rainbow trout production in mainland Europe.

Movement of live fish transporters between the UK and mainland Europe. Currently, the only trade in live salmonids is with the Republic of Ireland and the Channel Islands, which have equivalent health status to that of the UK (i.e. freedom from VHSV, IHNV and Gyrodactylus salaris). A number of companies operate lorries that transport live fish in both the UK and mainland Europe. The majority of these lorries operate in France, but some also travel to sites in other parts of Europe, for example Denmark, Belgium, Holland, Germany and eastern European countries, before returning to the UK.

Current risk reduction measures. Companies operating live fish transporters are advised by the Centre for Environment, Fisheries and Aquaculture Science (Cefas) that the vehicle should be cleaned out and disinfected between consignments of fish. However, no cleaning or disinfection is legally required.

Hazard description. The relevant information on the hazards is summarised in Table 3. This information was extracted from literature reviews of the 3 pathogens and was used to determine the likelihoods at each step in the pathway.

\section{Scenario tree}

The main risk of mechanical transmission of the identified hazards via a fish transporter returning from mainland Europe arises when the transporter is used for movements between farms when abroad (i.e. carries fish produced outside the UK). This scenario is modelled in Fig. 1. The likelihoods and associated uncertainty estimates for each step in the scenario are summarised in Table 4. Lorries delivering fish originating in the UK to a foreign farm and then immediately returning empty present a considerably lower risk. If the hazards are present on the farm receiving fish, the use of equipment carried on the lorry at the destination farm may result in very low levels of the hazard being transferred onto the lorry. It is also possible that small quantities of the hazard become attached to the wheels or clothing of the driver. It was concluded that these scenarios represent a negligible risk at Step 1; therefore, they were not explored further.

\section{Release assessment}

Step 1. The likelihood that a live fish transporter carries fish infected with VHSV, IHNV or Gyrodactylus salaris depends on the farm-level prevalence of the hazards. The distribution of the hazards is not well 
Table 3. Description of the infectious agents (information extracted from literature reviews). VHSV: viral haemorrhagic septicaemia virus; IHNV: infectious haematopoietic necrosis virus

\begin{tabular}{|c|c|c|c|}
\hline & VHSV & IHNV & Gyrodactylus salaris \\
\hline Transmission & $\begin{array}{l}\text { Shed in the urine of clinically } \\
\text { affected fish (Neukirch 1985). } \\
\text { Gills likely portal of entry (Meier } \\
\text { et al. 1994). Outbreaks linked to } \\
\text { feeding infected wild caught fish } \\
\text { (Dixon 1999); transmission via the } \\
\text { oral route not definitively proved. } \\
\text { Survivors carry the virus up to } 1 \text { yr } \\
\text { (Jørgensen 1982). }\end{array}$ & $\begin{array}{l}\text { Clinically affected fish shed virus } \\
\text { in faeces, urine, sexual fluids and } \\
\text { external mucus. Virus is isolated } \\
\text { up to } 50 \mathrm{~d} \text { after exposure (Drolet } \\
\text { et al. 1995). Gills likely portal of } \\
\text { entry (Meier et al. 1994). Vertical } \\
\text { transmission may also occur (virus } \\
\text { in sexual fluids) (Hattenberger- } \\
\text { Baudouy et al. 1995, Overturf } \\
\text { et al. 2001). }\end{array}$ & $\begin{array}{l}\text { Fish become infected through } \\
\text { contact with parasites in the } \\
\text { water column or through direct } \\
\text { contact with an infected fish or } \\
\text { substrate to which the parasite } \\
\text { has adhered (Bakke et al. 2007) }\end{array}$ \\
\hline $\begin{array}{l}\text { Survival } \\
\text { outside host }\end{array}$ & $\begin{array}{l}49 \mathrm{~d} \text { at } 10^{\circ} \mathrm{C} \text { in tap water and } 10 \mathrm{~d} \\
\text { at } 4^{\circ} \mathrm{C} \text { in mud (Ahne } 1982 \mathrm{a} \text { ). } \\
\text { Drying for } 28 \mathrm{~d} \text { at } 4^{\circ} \mathrm{C} \text { reduced } \\
\text { titre by } 99 \% \text { (Ahne } 1982 \mathrm{~b} \text { ). } \\
\text { Survives dry environment for } 7 \mathrm{~d} \\
\text { at } 4^{\circ} \mathrm{C}, 3-10 \mathrm{~d} \text { at } 17-22^{\circ} \mathrm{C} \text { (Frost \& } \\
\text { Wellhausen } 1974 \text { ) inactivated } \\
\text { within hours at temperatures } \\
\text { between } 35 \text { and } 50^{\circ} \mathrm{C} \text {. See EFSA } \\
\text { (2007) for details. }\end{array}$ & $\begin{array}{l}\text { Similar to VHSV. Survived in cell } \\
\text { culture supernatants for up to } 36 \\
\text { and } 16 \text { d at } 4 \text { and } 25^{\circ} \mathrm{C} \text {, } \\
\text { respectively (Hostnik et al. 2002); } \\
\text { culturable from viscera stored for } \\
1 \text { and } 3 \text { d at } 25 \text { and } 4^{\circ} \mathrm{C} \text {, } \\
\text { respectively (Hostnik et al. 2002). } \\
\text { Survival for up to } 9 \text { wk on } \\
\text { naturally occurring substances } \\
\text { (e.g. clay) (Yoshinaka et al. 2000) } \\
\text { and } 7 \text { wk in lake water } \\
\text { (Wedemeyer et al. 1978). See EFSA } \\
\text { (2007) for details. }\end{array}$ & $\begin{array}{l}\left.4 \mathrm{~d} \text { off the host (at } 3^{\circ} \mathrm{C}\right)(\mathrm{Olstad} \\
\text { et al. 2006) (maximum } 7 \mathrm{~d} \text {; } \\
\text { Mo 1997); doubled if parasites } \\
\text { remain on the dead host } \\
\text { (Olstad et al. 2006). Killed by } \\
\text { desiccation, freezing, elevated } \\
\text { temperatures and full strength } \\
\text { salinity (Soleng \& Bakke 1997). }\end{array}$ \\
\hline $\begin{array}{l}\text { Viral titre / } \\
\text { parasite } \\
\text { numbers }\end{array}$ & $\begin{array}{l}\text { High viral titres in the kidney and } \\
\text { spleen of clinically infected fish } \\
\left(4.5-6.8 \log _{10} \mathrm{TCID}_{50} \mathrm{~g}^{-1}\right) \text {, also } \\
\text { found in milt, ovarian fluid, liver, } \\
\text { heart and muscle (Wolf 1988). }\end{array}$ & $\begin{array}{l}\text { Isolated from naturally infected } \\
\text { pre-spawning fish from all major } \\
\text { organs, found at highest } \\
\text { concentration in the gills, } \\
\text { kidney, spleen and digestive tract } \\
\text { (Mulcahy et al. 1984). }\end{array}$ & $\begin{array}{l}\text { G. salaris (sensu strictu) - } \\
\text { adapted to Atlantic salmon- } \\
\text { exist on rainbow trout in very } \\
\text { low numbers (OIE 2003). } \\
\text { Rainbow trout-adapted } \\
\text { strains may achieve high } \\
\text { infection rates (Jørgensen et al. } \\
2007 \text { ) }\end{array}$ \\
\hline $\begin{array}{l}\text { Infectious } \\
\text { dose }\end{array}$ & $\begin{array}{l}\text { Minimum infectious dose } \\
\text { unknown. Oral route may require } \\
\text { high dose. Successful bath } \\
\text { challenge in rainbow trout by } \\
\text { immersion in } 25 \text { PFU ml }{ }^{-1} \\
\text { (Jørgensen 1992). }\end{array}$ & $\begin{array}{l}\text { Minimum infectious dose } \\
\text { unknown; transmission on shared } \\
\text { equipment (Hattenberger- } \\
\text { Baudouy et al. 1988, St-Hilaire } \\
\text { et al. 2002) indicates low infectious } \\
\text { dose. }\end{array}$ & $\begin{array}{l}\text { Single parasite } \\
\text { (Jansen \& Bakke 1991, } \\
\text { Harris et al. 1994). }\end{array}$ \\
\hline Disinfection & $\begin{array}{l}\text { Disinfectants (e.g. chlorine, } \\
\text { hypochlorites and iodophors) are } \\
\text { very effective at killing } \\
\text { rhabdoviruses (Smail 1999). }\end{array}$ & $\begin{array}{l}\text { Susceptible to a wide range of } \\
\text { disinfectants (e.g. chlorine and } \\
\text { iodophors); efficacy affected by } \\
\text { proteinaceous material } \\
\text { (Inouye et al. 1991). }\end{array}$ & $\begin{array}{l}\text { Killed by aluminium sulphate at } \\
202 \mu \mathrm{g}^{-1} \text { (Soleng et al. 1999, } \\
\text { Poléo et al. 2004), and most } \\
\text { disinfectants (e.g. iodine at } \\
250 \mathrm{mg} \mathrm{l}^{-1} ; \text { T. A. Mo pers. } \\
\text { comm.). }\end{array}$ \\
\hline $\begin{array}{l}\text { Geographic } \\
\text { distribution }\end{array}$ & $\begin{array}{l}\text { VHSV free zones established in } \\
\text { Europe. Most rainbow trout } \\
\text { production in areas of } \\
\text { unknown status. }\end{array}$ & $\begin{array}{l}\text { Small areas of mainland Europe } \\
\text { approved free of IHNV. }\end{array}$ & $\begin{array}{l}\text { Originally Baltic watershed; } \\
\text { now also Denmark } \\
\text { (Buchmann \& Bresciani 1997) } \\
\text { and Germany (Cunningham et } \\
\text { al. 2003), possibly more } \\
\text { widespread. }\end{array}$ \\
\hline $\begin{array}{l}\text { Farm-level } \\
\text { prevalence }\end{array}$ & No data & No data & $\begin{array}{l}\text { Rainbow trout-adapted strain in } \\
\text { high proportion of Danish } \\
\text { rainbow trout farms } \\
\text { (Buchmann \& Bresciani 1997, } \\
\text { Nielsen \& Buchmann 2001). }\end{array}$ \\
\hline $\begin{array}{l}\text { Within-farm } \\
\text { prevalence }\end{array}$ & No data & No data & No data \\
\hline
\end{tabular}


established. However, VHSV and IHNV are known to exist in farmed rainbow trout production throughout mainland Europe, with the exception of approved free areas. The distribution of $G$. salaris is even less well established outside of the Baltic watershed. It is not known if the parasite is present in France.

The estimated likelihood of the lorry visiting a farm with VHSV- or IHNV-infected stock is low and the likelihood of the farm having G. salaris infected stock very low; these estimates have a high level of uncertainty.

Step 2. The likelihood that the fish (or the transport water) are infected with the hazard depends on the prevalence of infection on the farm and the consignment size. Live fish transporters are generally used in rainbow trout production to move consignments of tens of thousands of juvenile fish from a hatchery to ongrowing sites. Thus, even if the hazard is present at a very low prevalence, as may be case for all 3 hazards, it will be present in the consignment.

The likelihood estimate for all 3 hazards is high with a low level of uncertainty.

Step 3. The likelihood of the hazard remaining on the lorry once the lorry has off-loaded the fish depends on the (1) prevalence of infection in the fish, (2) excretion of the VHSV and IHNV or shedding of Gyrodactylus salaris, and (3) likelihood that any dead fish remain on the lorry.

The farmer is unlikely to knowingly sell fish exhibiting clinical signs of infection; however, within a con-

Release assessment
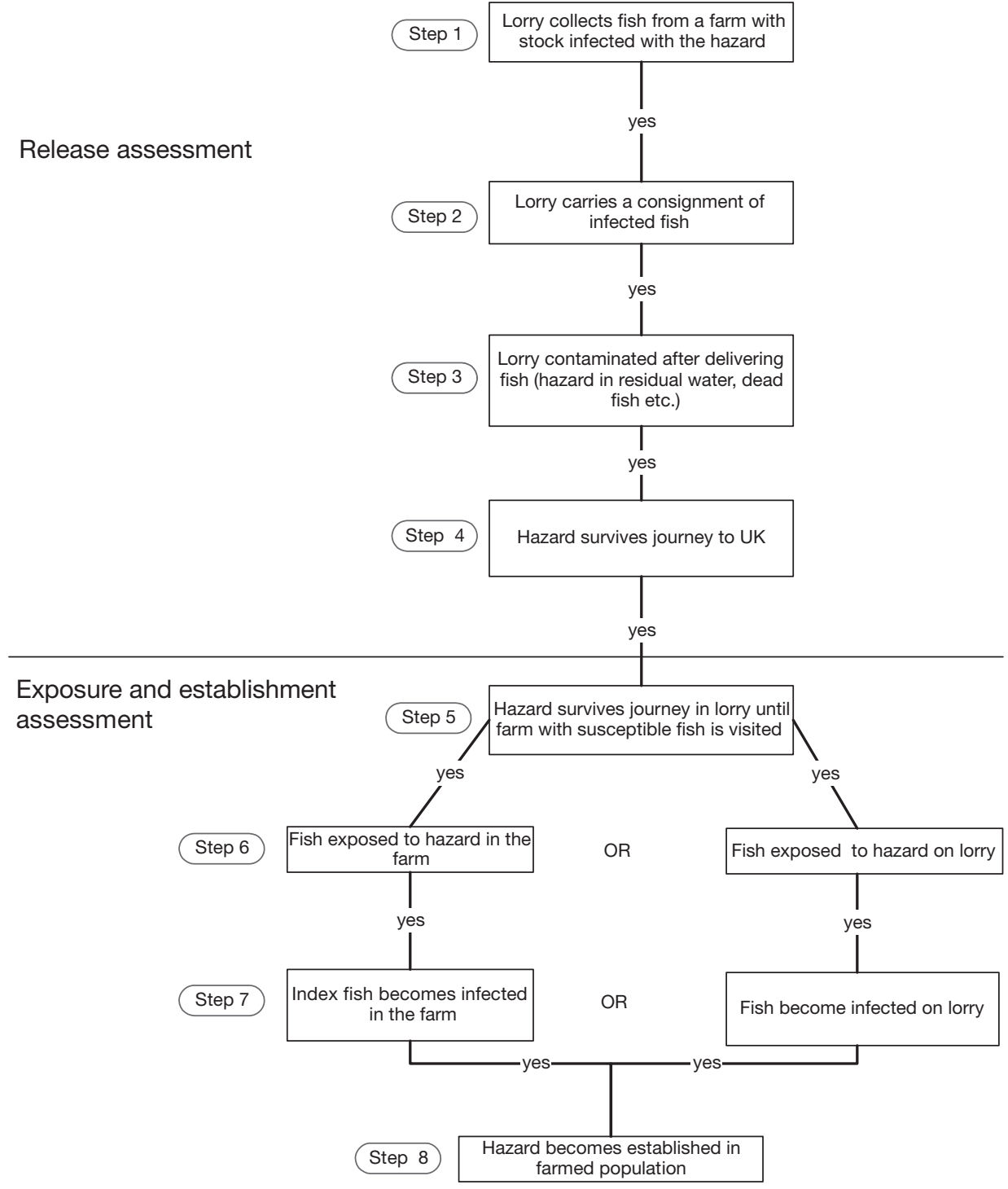

Fig. 1. Scenario tree for the introduction and establishment of viral haemorrhagic septicaemia virus (VHSV), infectious haematopoietic necrosis virus (IHNV) and Gyrodactylus salaris into the UK by fish transporters 
signment a small number of clinically affected fish may not be noticed. Thus, the majority of infected fish in the consignment will have subclinical infections of IHNV or VHSV. The stress of transport may result in the recrudescence of the viral infection and excretion of the virus and mortality; however, this is unlikely to occur during transport. Gyrodactylus salaris sensu stricto causes no clinical signs in rainbow trout, where prevalence is variable but generally low $(<5 \%)$ and abundance is low (OIE 2003). The rainbow trout adapted strain of $G$. salaris (which is more likely to be present in farmed rainbow trout than G. salaris sensu stricto) may be present at high prevalence and abundance. Prevalence and abundance will depend on the frequency of treatment for ectoparasites and environmental conditions. It is likely that G. salaris parasites will detach from infected fish during transport, resulting in contamination of the lorry.

The risk of contamination is low for VHSV and IHNV (with moderate uncertainty) and high for Gyrodactylus salaris (low uncertainty). Some mortality can be expected during transport, and if these dead fish remain in the lorry following delivery of the consignment, the likelihood of contamination with VHSV and IHNV increases to moderate.

Step 4. The survival of the pathogen on the journey to the UK will depend on the duration of the journey and the environmental conditions, notably temperature and humidity. The duration of the journey is highly variable from a maximum of approximately $3 \mathrm{~d}$ (e.g. from farms in Estonia) to less than $6 \mathrm{~h}$ (e.g. from farms in northern France). Evidence cited in Table 3 indicates that IHNV will not survive more than $3 \mathrm{~d}$ in viscera (at $4^{\circ} \mathrm{C}$ ). VHSV has similar survival characteristics and survival in viscera is likely to be of the same order. In the environment survival will be considerably longer. It can be concluded that the viral load in dead infected fish in the lorry will have decayed significantly before arrival in the UK. Free VHSV or IHNV in the environment will have survived better, especially at low temperatures. Conversely G. salaris will survive better on dead fish (where they continue to feed) than off the host (maximum $6 \mathrm{~d}$ ).

The amount of the hazard present will decline during the journey. However, some viable hazard is likely to persist. Therefore, the likelihood of survival during transport is judged to be high for all the hazards with a moderate level of uncertainty.

\section{Exposure assessment and establishment}

Step 5. On returning to the UK a lorry may travel directly to a farm site or alternatively to a depot. The time before exposure at a fish farm may occur varies from a few hours, to several days or even a week or more. The pathogen may have already survived a considerable period outside the host or in a dead host. The probability of continued survival in the transporter depends on the time spent at a depot and/or the duration of the onward journey from the UK border and environmental conditions (notably temperature and humidity). Elevated temperatures and desiccation will decrease the survival time.

During this step, the amount of hazard present will continue to decline and the probability that viable

Table 4. Unrestricted assessment of likelihoods for each step of the scenario tree (Fig. 1) (and conditional likelihoods in parentheses). See Table 1 for a description of qualitative terms and Table 2 for method for calculating conditional likelihood estimates. VHSV: viral haemorrhagic septicaemia virus; IHNV: infectious haematopoietic necrosis virus; G. salaris: Gyrodactylus salaris. For other abbreviations see Table 2

\begin{tabular}{|c|c|c|c|c|c|c|c|}
\hline \multirow{2}{*}{ Step } & \multirow{2}{*}{ Description } & \multicolumn{3}{|c|}{ — Likelihood (conditional) _— } & \multicolumn{3}{|c|}{-Uncertainty } \\
\hline & & VHSV & IHNV & G. salaris & VHSV & IHNV & G. salaris \\
\hline \multicolumn{8}{|c|}{ Release assessment } \\
\hline 1 & $\begin{array}{l}\text { Lorry collects fish from a farm stocked with } \\
\text { fish infected with the hazard }\end{array}$ & $\mathrm{L}$ & $\mathrm{L}$ & VL & $\mathrm{H}$ & $\mathrm{H}$ & $\mathrm{H}$ \\
\hline 2 & Lorry carries a consignment of infected fish & $\mathrm{H}(\mathrm{L})$ & $\mathrm{H}(\mathrm{L})$ & $\mathrm{H}(\mathrm{VL})$ & $\mathrm{L}$ & $\mathrm{L}$ & $\mathrm{L}$ \\
\hline 3 & Lorry contaminated after delivering fish & L (VL) & $\mathrm{L}(\mathrm{VL})$ & $\mathrm{H}(\mathrm{VL})$ & M & M & $\mathrm{L}$ \\
\hline 4 & Hazard survives journey to the UK & $\mathrm{H}(\mathrm{VL})$ & $\mathrm{H}(\mathrm{VL})$ & $\mathrm{H}(\mathrm{VL})$ & M & M & M \\
\hline \multicolumn{8}{|c|}{ Exposure assessment } \\
\hline 5 & Hazard survives journey to fish farm & $\mathrm{M}(\mathrm{VL})$ & $\mathrm{M}(\mathrm{VL})$ & $\mathrm{M}(\mathrm{VL})$ & $\mathrm{H}$ & $\mathrm{H}$ & $\mathrm{H}$ \\
\hline 6 & $\begin{array}{l}\text { Contact made between hazard and host } \\
\text { (on lorry or at first farm visited) }\end{array}$ & $\mathrm{M}(\mathrm{VL})$ & $\mathrm{M}(\mathrm{VL})$ & $\mathrm{M}(\mathrm{VL})$ & $\mathrm{L}$ & $\mathrm{L}$ & $\mathrm{L}$ \\
\hline \multicolumn{8}{|c|}{ Establishment } \\
\hline 7 & Hazard infects index case & VL (EL) & EL (N-EL) & $\mathrm{M}(\mathrm{VL})$ & $\mathrm{H}$ & $\mathrm{H}$ & M \\
\hline 8 & $\begin{array}{l}\text { On average more than one case results } \\
\text { from each infection }\end{array}$ & $\mathrm{M}(\mathrm{EL})$ & $M(N-E L)$ & $\mathrm{M}(\mathrm{VL})$ & $\mathrm{H}$ & $\mathrm{H}$ & $\mathrm{H}$ \\
\hline
\end{tabular}


virus or parasites remain is judged to be moderate for all the hazards, with high uncertainty due to variation in time from arrival in the UK to visiting a farm and conditions of transport.

Step 6. The hazard may gain access to a susceptible species in 2 ways. Firstly, in collecting fish at the first farm visited, the resident fish stocks may become exposed to the hazard if either dead fish on the transporter or contaminated water, enter the aquatic environment on the farm. the likelihood of this occurring is low for all hazards. Secondly, fish loaded on the transporter may become exposed to the hazard during transit. Thus, infected fish, or the hazard (present in the transport water) are delivered to the second farm. This route has a moderate likelihood with a low level of uncertainty.

The overall likelihood (considering both routes) of susceptible fish becoming exposed is moderate for all hazards, with low uncertainty.

Step 7. The likelihood that once introduced into a farm, the hazard will result in infection depends upon the level of challenge (e.g. viral dose or number of parasites), the viability of the pathogen and the susceptibility of the fish population. For the viral hazards a very high level of uncertainty exists since there are few data on the minimum infectious dose and the likely level of hazard to which the fish will be exposed. It is highly likely that initial viral contamination will be low and will decline during transport. A sufficient viral load may be delivered if dead fish are carried in the transporter at a low temperature (i.e. during winter), and are then scavenged. However, the oral route has not been established as a route of infection for IHNV. A single Gyrodactylus salaris parasite can result in an outbreak, since parasites carry progeny which are also pregnant; hence, they have been referred to as 'Russian dolls' (Bakke et al. 2007). Thus, the likelihood of establishment is higher (with less uncertainty) compared with the viral hazard.

The likelihood that exposure leads to infection for VHSV is very low, for IHNV is extremely low, and both carry a high level of uncertainty. The likelihood for G. salaris is moderate (with moderate uncertainty).

Step 8. The disease will only establish if the first fish to be infected (the index case) successfully infects another fish. The infection will establish if, on average, each infected fish infects more than one other fish (basic reproduction number, $R_{0}>1$ ) (Nokes \& Anderson 1988). The duration of infectivity and the effective contact rate between fish (i.e. contacts that result in transmission) will determine $R_{0}$. These parameters are not known for the hazards. However, rainbow trout farms stock fish at high densities that may result in high contact rates for horizontally transmitted diseases.
The likelihood for all hazards that they establish following the infection of the index case(s) is moderate, with a high level of uncertainty.

\section{Risk estimation}

Release assessment. Overall, the likelihood that a lorry will return to the UK carrying any of the 3 hazards is very low. Most uncertainty exists around the estimates of Step 1 (hazard is present on the farm).

Exposure assessment and establishment. Once release has taken place, the likelihood for all the hazards that exposure will take place is low (2 steps with medium likelihood estimates) with a high level of uncertainty at Step 5 (survival in the transporter before arrival at a farm). The likelihood that establishment will follow exposure is very low for VHSV, extremely low for IHNV and low for Gyrodactylus salaris. Both establishment steps (Steps 7 and 8) were judged to be highly uncertain for the viral hazards.

Release, exposure and establishment assessment. The overall estimate of release and exposure is extremely low, negligible to extremely low and very low for VHSV, IHNV and Gyrodactylus salaris, respectively. A total of 4 of the 8 steps had a high level of uncertainty for the viral hazards (3 steps had high uncertainty for $G$. salaris).

\section{Telephone survey}

All 5 British companies interviewed transport salmonids outside of the UK but do not transport any salmonid fish species between farm sites overseas. They operate in Ireland, France, Denmark, Germany, Portugal, Belgium and Spain. The main fish species transported are Atlantic salmon, rainbow trout, eel Anguilla anguilla and carp Cyprinus carpio. The companies operate between 1 and 5 vehicles and make between 2 and 15 journeys from mainland Europe to the UK per year. On return to the UK, the lorries travel either to depots $(n=2)$, farms $(n=2)$ or either a farm or $\operatorname{depot}(\mathrm{n}=1)$.

Lorries might be cleaned and disinfected after leaving a farm and before boarding a ferry for the return journey. The likelihood of cleaning and disinfection at any of these stages varies between companies and on the availability of the necessary facilities (i.e. water supply, hoses etc.). Four of the companies interviewed were not aware of any specialised disinfection facilities abroad. It is also possible that the transporter is cleaned but not disinfected: 3 of the companies interviewed do not disinfect their lorries before returning to the UK. All the companies interviewed thoroughly 
clean and disinfect their lorries in the UK irrespective of whether they had been cleaned or disinfected abroad.

Thorough cleaning will reduce or eliminate most contaminations and it can be assumed that cleaning will remove any dead or dying fish. However, inadequate cleaning may result in pools of water or sediment containing the pathogen or even dead fish remaining on the lorry. All companies interviewed stated that any dead fish (even small fingerlings) were very unlikely to remain in the tanks after cleaning. All 3 pathogens are susceptible to the majority of commercial disinfectants. If an unsuitable disinfectant or a poorly prepared effective disinfectant is used the pathogen might survive. The likelihood that VHSV, IHNV or Gyrodactylus salaris remain in the transporter following cleaning and disinfection is very low for VHSV and IHNV and extremely low for G. salaris.

\section{Restricted risk assessment}

A restricted assessment was made assuming cleaning and disinfection took place on return to the UK before the lorry visited another farm (Table 5), which was estimated to reduce the likelihood of Step 5 to very low for the viral hazards and extremely low for Gyrodactylus salaris. In the event of the hazard surviving cleaning and disinfection, the amount of hazard remaining will have been greatly reduced. Therefore, the likelihood of Steps 6 and 7 occurring is lower than is the case for an unrestricted analysis. The overall estimate for release, exposure and establishment is negligible for all 3 hazards.

\section{DISCUSSION}

This paper has 2 main components: a risk assessment for introduction of exotic pathogens via the movement of live fish transporters and a survey to determine current practices of live fish transporters based in the UK and currently operating in mainland Europe. Risk management was considered separately to risk assessment. The main findings are that if transporters made deliveries within Europe, the likelihood of introduction, exposure and establishment varied from very low (for Gyrodactylus salaris) to extremely low to negligible (for INHV). All the risk estimates carry a high level of uncertainty. The hazards will only establish if a susceptible individual is exposed to a minimum infectious dose. For the viral hazards, a very high level of uncertainty exists regarding both the amount of virus that remains on a lorry after it has moved a consignment containing infected fish, and the minimum infectious dose. Both lack of information and significant natural variability contribute to the total uncertainty. G. salaris has a higher likelihood of establishment, and less uncertainty, compared with the viral hazards, because it is known that only 1 parasite is needed to cause an outbreak. It is also very clear that this route is considerably more likely to introduce the rainbow troutadapted strain of G. salaris, than G. salaris sensu stricto. Other important sources of uncertainty are common to all the hazards. Whilst it was estimated that the likelihood that the lorry had collected fish from a farm where stock infected with the hazard was low or very low (for G. salaris), these estimates carry a high level of uncertainty due to the lack of

Table 5. Restricted assessment of likelihood of infection for each step of the scenario tree (Fig. 1) (and conditional likelihoods in parentheses). Cleaning and disinfection on arrival in the UK decreases likelihood at Step 5. See Table 1 for a description of qualitative terms and Table 2 for method for calculating conditional likelihood estimates.VHSV: viral haemorrhagic septicaemia virus, IHNV: infectious haematopoietic necrosis virus; G. salaris: Gyrodactylus salaris. For other abbreviations see Table 2

\begin{tabular}{|c|c|c|c|c|c|c|c|}
\hline \multirow[t]{2}{*}{ Step } & \multirow{2}{*}{ Description } & \multicolumn{3}{|c|}{ — Likelihood (conditional) __ } & \multicolumn{3}{|c|}{-Uncertainty } \\
\hline & & VHSV & IHNV & G. salaris & VHSV & IHNV & G. salaris \\
\hline \multicolumn{8}{|c|}{ Release assessment } \\
\hline 1 & $\begin{array}{l}\text { Lorry collects fish from a farm stocked with } \\
\text { fish infected with the hazard }\end{array}$ & $\mathrm{L}$ & $\mathrm{L}$ & VL & $\mathrm{H}$ & $\mathrm{H}$ & $\mathrm{H}$ \\
\hline 2 & Lorry carries a consignment of infected fish & $\mathrm{H}(\mathrm{L})$ & $\mathrm{H}(\mathrm{L})$ & $\mathrm{H}(\mathrm{VL})$ & $\mathrm{L}$ & $\mathrm{L}$ & $\mathrm{L}$ \\
\hline 3 & Lorry contaminated after delivering fish & $\mathrm{L}(\mathrm{VL})$ & L (VL) & $\mathrm{H}(\mathrm{VL})$ & M & M & $\mathrm{L}$ \\
\hline 4 & Hazard survives journey to the UK & $\mathrm{H}(\mathrm{VL})$ & $\mathrm{H}(\mathrm{VL})$ & $\mathrm{H}(\mathrm{VL})$ & M & M & $\mathrm{M}$ \\
\hline \multicolumn{8}{|c|}{ Exposure assessment } \\
\hline 5 & Hazard survives journey to fish farm & VL (EL) & VL (EL) & EL (N-EL) & $\mathrm{L}$ & $\mathrm{L}$ & $\mathrm{L}$ \\
\hline 6 & $\begin{array}{l}\text { Contact made between hazard and host } \\
\text { (on lorry or at first farm visited) }\end{array}$ & L (EL) & $\mathrm{L}(\mathrm{EL})$ & $\mathrm{L}(\mathrm{N})$ & $\mathrm{L}$ & $\mathrm{L}$ & $\mathrm{L}$ \\
\hline \multicolumn{8}{|c|}{ Establishment } \\
\hline 7 & Hazard infects index case & $\mathrm{EL}(\mathrm{N})$ & EL (N) & $\mathrm{L}(\mathrm{N})$ & $\mathrm{H}$ & $\mathrm{H}$ & M \\
\hline 8 & $\begin{array}{l}\text { On average more than one case results } \\
\text { from each infection }\end{array}$ & $\mathrm{M}(\mathrm{N})$ & $\mathrm{M}(\mathrm{N})$ & $\mathrm{M}(\mathrm{N})$ & $\mathrm{H}$ & $\mathrm{H}$ & $\mathrm{H}$ \\
\hline
\end{tabular}


data on the farm-level prevalence. The main factors determining the assessment of exposure are the conditions within the transporter and the time from entering the country to visiting a farm, which will vary greatly with time of year and between visits; hence, Step 5 has a high level of uncertainty (due mainly to natural variability).

Whilst all reasonable efforts were made to identify live transporters operating in mainland Europe, it is possible that some companies were not identified. Nevertheless, the responses from the companies contacted were consistent. All international movements of salmonid fish by the companies interviewed originate from UK farms. None of these companies transports foreign stocks of fish susceptible to VHS, IHN or Gyrodactylus salaris while abroad. However, it is possible that in the future some companies may extend their activities to include movements within Europe. The interviewees had a high awareness of the disease status in the countries their lorries visited and the potential implications of an exotic disease introduction to their own businesses and reputations as well as the disease status of the UK. It was concluded that strict cleaning and disinfection procedures are observed. The risk management currently practised by live fish operators based in the UK but operating in mainland Europe would reduce the estimated unrestricted likelihood to negligible. Given the number of lorries used in the UK and abroad together with the current risk management and operating practices (e.g. not moving fish between farms overseas), the current risk of exotic disease introduction is negligible. Since the unrestricted likelihood for all hazards is greater than negligible and highest for $G$. salaris, it is important that changes in the practices of operators working abroad are monitored. It is realistic to assume that some companies regularly sending vehicles to Europe could diversify into making movements between farms, or if market forces changed, new companies might enter into the market that might not follow the cleaning and disinfection procedures currently practiced. Consideration needs to be given to formalising the currently practised biosecurity measures through an industry Code of Practice. If companies change their current mode of operation and, for example, make deliveries between farms in mainland Europe, formalising or legislating cleaning and disinfection may be necessary. The risk of disease transfer by well-boats has been recognised, and guidelines to minimise the risk appear in a Code of Practice for well-boats transporting Atlantic salmon (Anonymous 2000).

The present paper raises a number of methodological issues about qualitative risk assessment. In quantitative analysis, uncertainty can be modelled as the distribution around the most likely, or mean, point estimate of a probability. An estimate of the uncertainty of the outcome is achieved through stochastic simulation. Furthermore, if the data allows, uncertainty due to lack of data and natural variability should be distinguished (Vose 2000). In the present paper, we make a qualitative estimate of the overall uncertainty at each step and discuss its source. Qualitative assessment of uncertainty is used in pest risk assessment, for example to assess the risks of introducing alien fish species (Copp et al. 2005). By assessing the uncertainty at each step in the pathway, future research to either collect missing data or better assess natural variation can be formulated. No well-developed method for combining qualitative estimates of likelihood or uncertainty is available currently. One approach is to assign quantitative estimates to each qualitative value to allow the probabilities to be multiplied together. However, this semi-qualitative approach suffers from a number of flaws, discussed by Morris \& Cogger (2006). A matrix approach to combine probability and impact is well established (Vose 2000) and used in IRA to combine the likelihood of introduction and establishment with consequences (Kahn et al. 1999). In this paper, we extended the approach to combine the likelihood of each step to produce an overall estimate of likelihood for the pathway, an approach recently applied elsewhere (EFSA 2007). This approach is unsophisticated, and once again has mathematical limitations (Cox 2008), but has the advantage of transparency. Cox (2008) highlighted the problem of 'range compression' that may arise when the same rating is given to different likelihoods. He also notes that matrices may also lead to errors in ranking hazards. Given the limitations of the qualitative approach and the high level of uncertainty at a number of steps in the pathway, the overall likelihood estimate is less important than other insights that the risk assessment provides.

In a quantitative analysis the amount of hazard released could be modelled by estimating an initial level of contamination and rate of decay. This qualitative analysis considers hazard release as a binary event: the event is considered to have a positive outcome if any amount of the hazard is present. The amount of hazard released is critical in determining the likelihood of establishment; thus, the qualitative approach, which does not take into account the amount of hazard released, is clearly limited. Quantitative microbial risk assessments, designed to assess a safe level of exposure to a microbrial hazard, involve modelling the dose-response association (National Research Council 1983). The same approach could be used in this analysis if the data allowed the association between level of exposure of the susceptible species and likelihood of infection to be modelled. 


\section{CONCLUSION}

Risk assessments are undertaken to support decision-making. The qualitative approach adopted in this paper provides a firm basis on which to consider policy development to reduce the risk of disease introduction via the movement of live fish transporters to an acceptable (e.g. negligible) level. Quantitative analysis would be of limited value whilst key parameter estimates (e.g. farm-level prevalence of the hazards and the minimum infectious dose for the viral hazards) are not known. The key question this analysis sought to address is whether the current measures to prevent disease introduction via live fish transporters are adequate or if additional measures (e.g. certification and inspection) are justified. Further research into viral load in subclinically infected fish, the minimum infectious dose and the distribution of the hazard in mainland Europe would allow a more accurate estimate of the risk of disease introduction via live fish transporters. On the basis of the currently available data, we conclude that the likelihood of the introduction, exposure and establishment of the identified hazards through the movement of live fish transporters, as currently operated, is negligible.

Acknowledgements. We gratefully acknowledge the cooperation of the companies who participated in the telephone survey. This work was funded by the UK Department for Environment, Food and Rural Affairs (Defra).

\section{LITERATURE CITED}

Ahne W (1982a) Untersuchungen zur Tenazität der Fischviren. Fortschr Vetmed 35:305-309

Ahne W (1982b) Vergleichende Untersuchung über die Stabilität von vier fischpathogenen Viren (VHSV, PFR, SVCV, IPNV). Zentbl Vetmed Reihe C 29:457-476

Anderson I (2002) Foot and mouth 2001: lessons to be learnt, inquiry report. The Stationery Office, London

Anonymous (2000) Final report of the Joint Government/ Industry Working Group on Infectious Salmon Anaemia (ISA) in Scotland. Scottish Executive, Aberdeen

Bakke TA, Cable J, Harris PD (2007) The biology of gyrodactylid monogeneans: the 'Russian-doll killers'. Adv Parasitol 64:161-376

Buchmann K, Bresciani J (1997) Parasitic infections in pondreared rainbow trout Oncorhynchus mykiss in Denmark. Dis Aquat Org 28:125-138

> Copp GH, Garthwaite R, Gozlan RE (2005) Risk identification and assessment of non-native freshwater fishes: a summary of concepts and perspectives on protocols for the UK. J Appl Ichthyol 21:371-373

Cox LA (2008) What's wrong with risk matrices? Risk Anal 28(2):497-512

Cunningham CO, Collins CM, Malmberg G, Mo TA (2003) Analysis of ribosomal RNA intergenic spacer (IGS) sequences in species and populations of Gyrodactylus (Platyhelminthes: Monogenea) from salmonid fish in northern Europe. Dis Aquat Org 57:237-246
Dixon PF (1999) VHSV came from the marine environment: clues from the literature, or just red herrings? Bull Eur Assoc Fish Pathol 19:60-65

$>$ Drolet BS, Chiou PP, Heidel J, Leong JAC (1995) Detection of truncated virus particles in a persistent RNA virus infection in vivo. J Virol 69:2140-2147

EFSA (European Food Safety Authority) (2007) Scientific opinion of the Panel on Animal Health and Welfare on a request from the European Commission on possible vector species and live stages of susceptible species not transmitting disease as regards certain fish diseases. EFSA J 584: $1-163$

Frost JW, Wellhausen S (1974) Studies on the effect of temperature and glycerol on the inactivation of the virus of haemorrhagic septicaemia (VHS) of rainbow trout by use of the microtiter system. Zentbl Vetmed Reihe B 21: 625-631

Hammell KL, Dohoo IR (1999) The epidemiology of hemorrhagic kidney syndrome - infectious salmon anaemia in Atlantic salmon in Atlantic Canada. In: Thrusfield M, Goodall E (eds) Proceedings of the annual meeting of the Society for Veterinary Epidemiology and Preventive Veterinary Medicine, Bristol, p 211-221

Harris PD, Jansen PA, Bakke TA (1994) The population age structure and reproductive biology of Gyrodactylus salaris Malmberg (Monogenea). Parasitology 108:167-174

Hattenberger-Baudouy AM, Danton M, Merle G (1988) Infectious haematopoietic necrosis (IHN) in Salmonidae. 2. Epidemiological data in France. Piscic Fr 91:10-13

> Hattenberger-Baudouy AM, Danton M, Merle G, de Kinkelin $P$ (1995) Epidemiology of infectious hematopoietic necrosis (IHN) of salmonid fish in France: study of the course of natural infection by combined use of viral and seroneutralization test and eradication attempts. Vet Res 26:256-275

- Hervé-Claude LP, Carpenter TE, Hedrick RP (2008) Risk of introducing viral hemorrhagic septicemia virus (VHSV) to the Chilean South Pacific via sardine imports from Europe. Dis Aquat Org 78:199-207

> Hostnik P, Barlic-Maganja D, Strancar M, Jencic V, Toplak I, Grom J (2002) Influence of storage temperature on infectious hematopoietic necrosis virus detection by cell culture isolation and RT-PCR methods. Dis Aquat Org 52:179-184

Inouye K, Ikeya F, Yamazaki T, Hara T (1991) Virucidal activities of various germicides to infectious haematopoeitic necrosis virus (IHNV). Fish Pathol 26:189-194

Jansen PA, Bakke TA (1991) Temperature-dependent reproduction and survival of Gyrodactylus salaris Malmberg, 1957 (Platyhelminthes: Monogenea) on Atlantic salmon (Salmo salar L.). Parasitology 102:105-112

> Jørgensen TR, Larsen TB, Jørgensen LG, Bresciani J, Kania PW, Buchmann K (2007) Characterisation of a low pathogenic form of Gyrodactylus salaris from rainbow trout. Dis Aquat Org 73:235-244

Kahn SA, Beers PT, Findlay VL, Peebles IR, Durham PJ, Wilson DW, Gerrity SE (1999) Import risk analysis on nonviable salmonids and non-salmonids. Marine Finfish, Australian Quarantine and Inspection Service, Canberra

Kennedy CR, Fitch DJ (1990) Colonization, larval survival and epidemiology of the nematode Anguillicola crassus, parasitic in the eel, Anguilla anguilla, in Britain. J Fish Biol 36:117-131

> Meier W, Schmitt M, Wahli T (1994) Viral haemorrhagic septicaemia (VHS) of nonsalmonids. Annu Rev Fish Dis 4:359-373

Mo TA (1997) Taksonomiske og biologiske undersokelser, virksomheten i 1986 og forslag til virksomhet i 1987. University of Oslo, Oslo 
Morris RS, Cogger N (2006) Scaling of outcomes in semiquantitative risk analysis - traps and tricks. Proc 11th Symp of the International Society for Veterinary Epidemiology and Economics, Cairns. ISVEE 11:904

Mulcahy D, Jenes C, Pascho R (1984) Appearance and quantification of infectious hematopoietic necrosis virus in female sockeye salmon (Oncorhynchus nerka) during their spawning migration. Arch Virol 80:171-181

Murray AG, Smith RJ, Stagg RM (2002) Shipping and the spread of infectious salmon anemia in Scottish aquaculture. Emerg Infect Dis 8:1-5

National Research Council (1983) Risk assessment in the federal government: managing the process. National Academy Press, Washington, DC

Neukirch M (1985) Uptake, multiplication, and excretion of viral haemorrhagic septicaemia virus in rainbow trout (Salmo gairdneri) In: Ellis AE (ed) Fish and shellfish pathology. Academic Press, Oxford, p 295-300

Nielsen CV, Buchmann K (2001) Occurrence of Gyrodactylus parasites in Danish fish farms. Bull Eur Assoc Fish Pathol 21:19-25

Nokes DJ, Anderson RM (1988) The use of mathematical models in the epidemiological study of infectious diseases and in the design of mass immunization programmes. Epidemiol Infect 101(1):1-20

OIE (World Organisation for Animal Health) (2001) Risk analysis in aquatic animal health. In: Rodgers CJ (ed) OIE International Conference on Risk Analysis in Aquatic Animal Health. Office International des Epizooties, Paris

OIE (World Organisation for Animal Health) (2003) Manual of diagnostic tests for aquatic animals, 4th edn. Office International des Epizooties, Paris

OIE (World Organisation for Animal Health) (2006) Aquatic Animal Health Code, 8th edn. Office International des Epizooties, Paris

Olstad K, Cable J, Robertsen G, Bakke TA (2006) Unpredicted transmission strategy of Gyrodactylus salaris (Monogenea: Gyrodactylidae): survival and infectivity of parasites on dead hosts. Parasitology 133:33-41

Overturf K, Lapatra S, Powell M (2001) Real-time PCR for the detection and quantitative analysis of IHNV in salmonids. J Fish Dis 24:325-333

Peeler EJ, Thrush MA (2004) Qualitative analysis of the risk of introducing Gyrodactylus salaris into the United Kingdom. Dis Aquat Org 62:103-113

Peeler EJ, Murray AG, Thebault A, Brun E, Giovaninni A, Thrush MA (2007) The application of risk analysis in aquatic animal health management. Prev Vet Med 81: $3-20$

Editorial responsibility: Julie Bebak, Auburn, Alabama, USA
Poléo ABS, Schjolden J, Hansen H, Bakke TA, Mo TA, Rosseland BO, Lydersen E (2004) The effect of various metals on Gyrodactylus salaris (Platyhelminthes, Monogenea) infections in Atlantic salmon (Salmo salar). Parasitology 128:169-177

Smail DA (1999) Viral haemorrhagic septicaemia. In: Woo PTK, Bruno DW (eds) Fish diseases and disorders, Vol 3. Viral, bacterial and fungal infections. CABI Publishing, Oxford, p 123-147

Soleng A, Bakke TA (1997) Salinity tolerance of Gyrodactylus salaris (Platyhelminthes, Monogenea): laboratory studies. Can J Fish Aquat Sci 54:1837-1845

Soleng A, Poléo ABS, Alstad NEW, Bakke TA (1999) Aqueous aluminium eliminates Gyrodactylus salaris (Platyhelminthes, Monogenea) infections in Atlantic salmon. Parasitology 119:19-26

St-Hilaire S, Ribble CS, Stephen C, Anderson E, Kurath G, Kent ML (2002) Epidemiological investigation of infectious hematopoietic necrosis virus in salt water net-pen reared Atlantic salmon in British Columbia, Canada. Aquaculture 212:49-67

Vagsholm I, Djupvik HO, Willumsen FV, Tveit AM, Tangen K (1994) Infectious salmon anaemia (ISA) epidemiology in Norway. Prev Vet Med 19:277-290

Vestergård Jørgensen PE (1982) Egtved virus: temperaturedependent immune response of trout to infection with low-virulence virus. J Fish Dis 5:47-55

Vestergård Jørgensen PE (1992) Recent advances in surveillance and control of viral haemorrhagic septicaemia (VHS) in trout. In: Kimura T (ed) OJI International Symposium on Salmonid Diseases. Hokkaido University Press, Hokkaido, p 60-71

Vose D (2000) Risk analysis - a quantitative guide. John Wiley \& Sons, Chichester

Wedemeyer GA, Nelson NC, Smith CA (1978) Survival of the salmonid viruses infectious hematopoietic necrosis (IHNV) and infectious pancreatic necrosis (IPNV) in ozonated, chlorinated, and untreated waters. J Fish Res Board Can 35:875-879

Wolf K (1988) Infectious viral haemorrhagic septicaemia. In: Wolf $\mathrm{K}$ (ed) Fish viruses and fish viral diseases. Cornell University Press, Ithaca, NY, p 217-249

WTO (World Trade Organisation) (1995) Agreement on the application of sanitary and phytosanitary measures. World Trade Organisation, Geneva

Yoshinaka T, Yoshimizu M, Ezura Y (2000) Adsorption and infectivity of infectious hematopoietic necrosis virus (IHNV) with various solids. J Aquat Anim Health 12: $64-68$

Submitted: June 30, 2008; Accepted: September 17, 2008

Proofs received from author(s): February 4, 2009 